\title{
当科に㧍ける真珠腫症手術治療の現況
}

\author{
暁 清文・佐藤 英光 - 浅井 真紀 \\ 黒川 浩伸・杉田 俊明・柳原 尚明
}

\section{Results of Surgery for Middle Ear Cholesteatoma}

\author{
Kiyofumi Gyo, Hidemitsu Sato, Masanori Asai, \\ Hironobu Kurokawa, Tosiaki Sugita and Naoaki Yanagihara \\ (Ehime University)
}

Operative findings and results in cases of middle ear cholesteatoma were analyzed with special reference to postoperative hearing and recurrence of cholesteatoma. Of the 242 ears operated. on in the past 9 years and 9 months, intact canal wall tympanoplasty was performed in 114 ears, tympanoplasty with the posterior canal wall removal in 81 ears, and radical mastoidectomy in 47 ears. Of the 139 ears observed for more than 6 months after tympanoplasty, postoperative hearing was improved in 34 ears $(24.5 \%)$, decreased in 15 ears $(9.3 \%)$ and still in the range of the preoperative level in 90 ears $(66.2 \%)$. Recurrence of the cholesteatoma was found in 15 ears $(6.2 \%)$, five of which had been treated by radical mastoidectomy. Though there were no such recurrences in 46 patients treated by staged intact canal wall tympanoplasty, a retraction pocket which was considered to be a precursor of cholesteatoma was found in seven cases $(15.2 \%)$. In order to avoid a retraction pocket in intact canal wall tympanoplasty, closure of the attic accompanied by obliteration of the mastoid cavity is advised.

Key words: cholesteatoma, ossicular reconstruction, hydroxyapatite ceramic, retraction pocket

はじめに

真珠腫症は骨破壊傾向が強く, 顔面神経麻痺 や硬膜外膿瘍などの合併症をきたしやすいとと から，その治療には原則的に手術治療が必要で ある。しかし，真珠腫の完全除去はしばしば困 難であり，特に聴力を保存しようとすれば再発 傾向が高まるなど問題が多い，乙のため我々は
極力, 外耳道後壁の保存につとめ, 段階的手術 を採用するようにしている1). 今回, 当科にて 真珠腫症で手術を行った症例の手術所見・治療 成績等について検討を行ったので報告する.

対 象

対象は炤和51年 10 月から㭼和 61 年 6 月までの 間に真珠腫症の診断で当科にて手術を行った 
226名（242耳）である。乙のうち男性は143名 (153耳)，女性は83名（89耳）であった。患者 の性別・年齢分布を表 1 亿示す。なお，雨側手 術例は16例で, うち10才未満は 4 例であった。

242 耳中，過去に手術の既往のない初回手術 例は179耳であった。乙のうちの 105 耳に外耳道 を保存する closed method を，74耳に外耳道 後壁を削開する open method を用いた。一 方, 手術既往のある再手術例は63耳で, てのう ちの54耳にはすでに open method が施され ていた。これらの症例には後壁再建は行って いない，外耳道後壁の残されていた 9 耳には closed methodを用いた。

\section{結 果}

術前の耳漏の多寡について調べたとてろ, 「多い」が62耳，「少ない」が86耳，「ない」が 69耳，不明が25耳であった。本症では必ずし屯 耳漏は著明でないことが分かる，細菌検査の行 われた症例について, 重複感染例屯含める之, 変形菌51耳, 緑膿菌33耳, 黄色ブドウ球菌 19 耳, 真菌 5 耳, その他の菌が44耳から検出され た。

耳小骨連鎖の再建は 163 耳で行った. このう ち closed method によるものが88耳, open method によるあのが75耳であった。この中に は第二次段階手術時に耳小骨連鎖を再建する予 定だが, 現在は連鎖が再建されていない状態, すなわち，いわゆる 0 型となっている32耳は含 まれていない，手術成績の評価は日本監床耳科 学会用語委员会による鼓室形成術の成績判定案 によった。この案によると 1) A-B gap $20 \mathrm{~dB}$ 以内, 2 ) 聴力レベル $40 \mathrm{~dB}$ 以内, 3 ) 聴力改 善 $15 \mathrm{~dB}$ 以上，のいずれかに該当するものを成 功例とするが, さらに A-B gap による判定法 屯あり, 術前の骨導聴力之術後の気導聴力を比 較して, $-10 \sim 10 \mathrm{~dB}$ : 著明改善, $11 \sim 20 \mathrm{~dB}$ : 改善, $21 \sim 30 \mathrm{~dB}$ : やや改善, $31 \mathrm{~dB} \sim$ : 不良之 し, 著明改善例之改善例を鼓室形成術成功例之 している．いずれにしろ，ての際の術後聴力の 評価は術後 6 ケ月以上経過してから行う. 今回
の真珠腫症例の手術成績評価では, 術前と最終 外来受診時の 4 分法による平均純音聴力レベル を比較した。術後 6 ケ月以上経過を観察した 139 耳についてみると，上記の 3 条件のいずれ かを満たすすのを成功例とすると，成功例は89 耳（64\%）であった。A-B gap による評価の 結果を表 2 亿示す。全体としてみると, 著明改 善38耳 $(27.3 \%)$, 改善34耳 $(24.5 \%)$, やや改 善34耳 $(24.5 \%)$ ，不良33耳 $(23.7 \%)$ であっ た。外耳道後壁を保存した場合と削開した場合 とを比較すると，著明改善と改善とを合わせた 前者の成功例数は 75 耳中 50 耳 $(66.7 \%)$ 亿対 し, 後者は64耳中 22 耳 $(34.4 \%)$ と後壁保存例 の才が聴力改善成績は良好であった.

耳小骨速鎖再建の際， III型変法ないしIV型変 法に使用したコルメラ材料は, 多孔性テフロ ン, セラミック, 自家耳小骨, 軟骨, 皮質骨, 同種骨など雑多である。最近，当科では水酸化 アパタイト製人工耳小骨（アパセラム®）帛を用 いることが多いので，乙れを他の材料を用いた 場合の成績と比較した。 A-B gap による評価 の結果を表 3 に示す．III型变法ではアパセラム による手術成功例は 17 耳中 $10 耳(58.8 \%)$ ， そ の他の材料の壦合は48耳中 28 耳 $(58.3 \%)$ で, この評価法では再建材料により手術成績に差は みられなかった。しかし著明改善例に限ると前 者が 7 耳 $(41.2 \%)$ ，後者が16耳 (33.3\%) 之 アパセラム使用例の方が良好な結果であった。

$\mathrm{IV}$ 型変法ではアパセラムの場合の成功例は 17 耳 中11耳 (64.7\%), その他の材料の場合は $12 耳$ 中 3 耳 $(25 \%)$ と, やはりアパセラム使用例の ナが手術成績は良好であった。

表 4 は術後観察中に問題のあった症例の頻度 を示す. 真珠腫の術後再発は15耳でみられた が, 遺残再発は段階手術例の 4 耳, 一期手術例 の 2 耳ならびに根治術例の 2 耳（錐体尖真珠腫 例）で, 他は再形成再発と思われた。 これら症 例の真珠腫再発までの期間は, 1 年以内が 7 耳, 1 年から 2 年が 2 耳, 2 年から 3 年が 2 耳, 3 から 4 年が 1 耳, 5 年以上が 3 耳であっ 
表 I 真珠腫症手術患者の性別, 年齢分布

\begin{tabular}{|c|c|c|c|c|c|c|c|c|c|}
\hline \multicolumn{2}{|c|}{ 年齿 } & \multirow{2}{*}{$\frac{0-9 才}{21 人}$} & \multirow{2}{*}{$\frac{\mid 10-19 才}{(21 人}$} & \multirow{2}{*}{$\frac{20-29 才}{25 人}$} & \multirow{2}{*}{$\frac{\mid 30-39 才}{\left(\begin{array}{c}29 人 \\
(1)\end{array}\right.}$} & \multirow{2}{*}{$\frac{40-49 才}{24 人}$} & \multirow{2}{*}{$\frac{50-59\rfloor}{\left(\begin{array}{c}18 人 \\
(1)\end{array}\right.}$} & \multirow{2}{*}{$\frac{60-69 才}{\left(\begin{array}{l}7 \\
1\end{array}\right)}$} & \multirow{2}{*}{$\frac{70-79 才}{1 人}$} \\
\hline 男 & 性 & & & & & & & & \\
\hline 女 & 性 & $\begin{array}{l}4 \\
(1)\end{array}$ & 6 & $\begin{array}{c}17 \\
(2)\end{array}$ & $\begin{array}{c}24 \\
(1)\end{array}$ & 11 & $\stackrel{14}{(1)}$ & $\left(\begin{array}{l}4 \\
1\end{array}\right)$ & 0 \\
\hline & & $\begin{array}{c}25 \\
(4)\end{array}$ & $\begin{array}{c}27 \\
(3)\end{array}$ & $\begin{array}{c}42 \\
(3)\end{array}$ & $\begin{array}{c}53 \\
(2)\end{array}$ & 35 & $\begin{array}{c}32 \\
(2)\end{array}$ & $\left(\begin{array}{c}11 \\
2\end{array}\right)$ & $\left(\begin{array}{l}1 \\
0\end{array}\right)$ \\
\hline
\end{tabular}

（）内はそのうちの両側手術例数

表 2 鼓室形成術による聴力改善成績

術前の骨導値と術後の気導值との差から A-B gap を求め, 手術成績の評価を行った。一10〜 $10 \mathrm{~dB}$ : 著明改善, $11 \sim 20 \mathrm{~dB}$ : 改善, $21 \sim 30 \mathrm{~dB}$ : やや改善, $31 \mathrm{~dB} \sim$ : 不良. (耳数)

\begin{tabular}{|c|c|c|c|c|c|c|c|c|c|c|c|c|c|}
\hline 術式 & \multirow{2}{*}{$\underset{\text { 保 }}{\mathrm{I}}$} & \multirow{2}{*}{$\underset{\text { 保 }}{\text { II }}$} & \multicolumn{2}{|c|}{ III } & \multicolumn{2}{|c|}{ IV } & \multicolumn{2}{|c|}{ III 変法 } & \multicolumn{2}{|c|}{ NV変法 } & \multicolumn{2}{|c|}{ 小 計 } & \multirow{2}{*}{ 計 } \\
\hline 外耳道 & & & 保 & 削 & 保 & 削 & 保 & 削 & 保 & 削 & 保 & 削 & \\
\hline \multicolumn{14}{|l|}{ 術後聴力 } \\
\hline 著明改善 & 5 & 2 & 0 & 3 & 0 & 0 & 16 & 7 & 3 & 2 & 26 & 12 & 38 \\
\hline 改 善 & 4 & 1 & 0 & 5 & 0 & 0 & 11 & 4 & 8 & 1 & 24 & 10 & 34 \\
\hline やや改善 & 0 & 0 & 2 & 8 & 0 & 0 & 8 & 8 & 6 & 2 & 16 & 18 & 34 \\
\hline 不 良 & 1 & 0 & 1 & 10 & 1 & 2 & 2 & 9 & 4 & 3 & 9 & 24 & 33 \\
\hline \multirow{2}{*}{ 計 } & \multirow{2}{*}{10} & \multirow{2}{*}{3} & 3 & 26 & 1 & 2 & 37 & 28 & 21 & 8 & \multirow{2}{*}{75} & \multirow{2}{*}{64} & \multirow{2}{*}{139} \\
\hline & & & \multicolumn{2}{|c|}{29} & \multicolumn{2}{|c|}{3} & \multicolumn{2}{|c|}{65} & \multicolumn{2}{|c|}{29} & & & \\
\hline
\end{tabular}

保：外耳道保存, 削：外耳道後壁削開

表 3 水酸化アパタイト（アパセラム）と他の材料による耳小骨連鎖 再建手術成績の比較 評価法は表 2 と同じ.

(耳数)

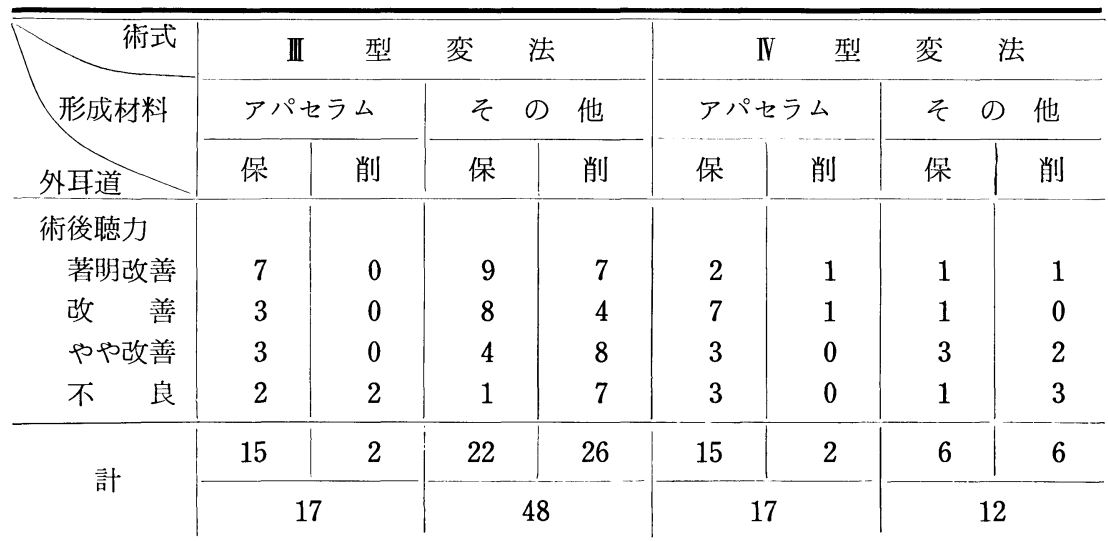

保: 外耳道保存, 削: 外耳道後壁削開 
た．再発例に対しては，すでに根治術がおてな われていた 2 耳を含め， 7 耳で再手術をおてな い最終的に根治術とした。他の 8 耳では外来処 置にて真珠腫を除去し，現在，経過観察中であ る。なお，いわゆる乳突腔真珠腫は後壁削開群 の 2 耳でみられた。 二次手術を完了した段階手 術例では現在の所, 後壁を削開した 1 耳で再形 成再発をきたしたのを除き真珠腫の再発はない が， 7 耳で retraction pocket の形成がみら れた。術後の耳漏は24耳でみられたが, 真珠腫 再発を伴わない場合は，後壁を削開した 2 耳を 除き，外来治療にて短期日のうちに治癒した。 削開群の 2 耳では長期にわたり耳漏が持続し た. 最終的に根治術を行った 47 耳の内， 5 耳に 側頭筋有茥弁を用いた乳突・鼓室・外耳道全閉
鎖術 ${ }^{3)}$ を行ったが，現在までのとてろ，乙れら の症例に真珠腫の再発はない。なお，乙の表に は示されていないが段階手術例72耳のうち, 後 壁保存例46耳中 21 耳 $(45.6 \%)$, 削開例26例中 6 耳 $(23 \%)$ の計 27 耳 $(37.5 \%)$ で, 第二次段 階手術時に真珠腫の遺残を認めた。いずれにし ろ一回の手術ではかなりの割合で真珠腫が遺残 するあの上考えられた.

術前の鼓膜所見による真珠腫の分類 ${ }^{4}$ 之術後 の真珠腫再発ならびに第二次段階手術時に真珠 腫遺残のみられた症例の割合を表 5 亿示す。真 珠腫分類の都合上，初回手術例に限っての統計 であり，再手術例の結果は除外した。鼓膜所見 による分類では, 頻度的には弛緩部穿孔が大部 分を占め，次いで後上部呀孔が多いが，战膜罒：

表 4 術後の問題点

（）内は真珠腫再発のため根治術を行った症例数.

*: 根治術例のなかには迷路摘出術の 4 例を含めた。

**: 最終的に根治術をおてなった症例数は 47 例.

(耳数)

\begin{tabular}{|c|c|c|c|c|c|c|c|c|}
\hline \multirow{3}{*}{ 手術術式 } & \multicolumn{3}{|c|}{ 外耳道後壁保存（114耳） } & \multicolumn{4}{|c|}{ 後 壁 削 開 (128耳) } & \multirow{3}{*}{ 計 } \\
\hline & \multicolumn{3}{|c|}{ 鼓 室 形 成 術 } & \multicolumn{3}{|c|}{ 鼓 室 形 成 術 } & \multirow{2}{*}{ 根治術 } & \\
\hline & 段階手術 & 段階一次 & 一期手術 & 段階手術 & 段階一次 & 一期手術 & & \\
\hline 症 例 数 & 46 & (27 & $\begin{array}{c}44 \\
(2)\end{array}$ & 26 & $\begin{array}{l}7 \\
1\end{array}$ & $\begin{array}{c}50 \\
(1)\end{array}$ & $42^{* *}$ & 242 \\
\hline $\begin{array}{l}\text { 術後の問題点 } \\
\text { 直珠腫の再登 }\end{array}$ & 0 & 2 & 3 & 1 & 1 & 3 & 5 & 15 \\
\hline Retraction Pocket & 7 & 1 & 5 & 0 & 0 & 0 & - & 13 \\
\hline 耳漏 & 2 & 1 & 2 & 3 & 1 & 7 & 8 & 24 \\
\hline 鼓膜穿孔 & 3 & 0 & 3 & 1 & 0 & 1 & - & 8 \\
\hline
\end{tabular}

表 5 術前の鼓膜所見による真珠腫の分類と術後再発ならびに 第二次段階手術時の真珠腫遺残 (耳数)

\begin{tabular}{|c|c|c|c|c|c|c|c|}
\hline 真珠腫の分類 & $\begin{array}{l}\text { 弛緩部 } \\
\text { 牚孔型 }\end{array}$ & $\begin{array}{l}\text { 後上部 } \\
\text { 穿孔型 }\end{array}$ & $\begin{array}{l}\text { 大穿孔 } \\
\text { 癒着型 }\end{array}$ & $\begin{array}{l}\text { 中心 } \\
\text { 穿 }\end{array}$ & $\begin{array}{l}\text { 鼓 膜 } \\
\text { 正 常 }\end{array}$ & その他 & 計 \\
\hline 耳 & 95 & 32 & 17 & 16 & 4 & 15 & 179 \\
\hline 術後の再発 & 8 & 3 & 1 & 0 & 0 & 1 & 13 \\
\hline 段階手術耳数 & 37 & 18 & 7 & 6 & 2 & 2 & 72 \\
\hline $\begin{array}{l}\text { 第二段階手術 } \\
\text { 時に真珠腫 }\end{array}$ & $\begin{array}{c}11 \\
(30 \%)\end{array}$ & $\begin{array}{c}6 \\
(33 \%)\end{array}$ & $\begin{array}{c}5 \\
(71 \%)\end{array}$ & $\begin{array}{c}4 \\
(67 \%)\end{array}$ & $\begin{array}{c}0 \\
(0 \%)\end{array}$ & $\begin{array}{c}1 \\
(50 \%)\end{array}$ & 27 \\
\hline
\end{tabular}


常例屯 4 例みられた. このうちの 2 例は先天性 と考えられたが，他の 2 例はいずれも乳幼児期 に滲出性中耳炎で鼓膜切開を受けた既往のある 症例である。術後再発に関しては群によりそれ ほどの差はみられなかった。第二次段階手術時 の真珠腫遺残に関しては，例数は少ないものの 大穿孔癒着型や中心穿孔型の再発頻度が高かっ た.

手術時の鼓室所見と術後の真珠腫再発ならび に第二次段階手術時に真珠腫遺残のみられた症 例の割合を表 6 亿示す，鼓室内に真珠腫の進展 がみられた症例に真珠腫の遺残が多いのは当然 としても，鼓室病変が軽いと思われた症例にも 遺残はみられた。

真珠腫症の合併症は58例（24\%）にみられ た。内訳は側頭葉膿瘍 1 例, 㹬膜外膿瘍 7 例,
顔面神経麻瘏10例，迷路炎 7 例，迷路瘦孔33例 であった。なお，ここで言う迷路炎はめまいを きたした症例の数を示した。これら迷路炎症例 のうちの 4 例には迷路摘出術を施行した.

手術後の患者の受診状況を表 7 に示す. 術後 短期間しか受診していない例の多くは近医にて 観察が行われている症例ではあるが，真珠腫症 では長期にわたる観察が必要とされているの で，今後とれらの症例の現況について検討した いと考えている。

\section{考案}

真珠腫症の手術術式については古くから open method とするか closed method とす るかで議論がある．外耳道後壁を削開して open method とすれば, 1) 真珠腫の除去が 容易である，2）術後は乳突洞腔が外耳之連な

表 6 手術時の鼓室所見と術後の真珠腫再発ならびに 第二次段階手術時の真珠腫遺残

(耳数)

\begin{tabular}{c|c|c|c|c|c|c}
\hline \hline 鼓 室 病 変 & 正 常 & 粘膜炎 & 肉芽炎 & 真珠腫 & その他 & 計 \\
\hline 耳 数 & 33 & 29 & 42 & 129 & 9 & 242 \\
術後の再発 & 4 & 1 & 3 & 7 & 0 & 15 \\
\hline 段階手術耳数 & 8 & 6 & 11 & 46 & 1 & 72 \\
$\begin{array}{c}\text { 第2 段階手術 } \\
\text { 時に真珠腫 }\end{array}$ & $\begin{array}{c}1 \\
(13 \%)\end{array}$ & $\begin{array}{c}0 \\
(0 \%)\end{array}$ & $\begin{array}{c}3 \\
(27 \%)\end{array}$ & $\begin{array}{c}23 \\
(50 \%)\end{array}$ & $\begin{array}{c}0 \\
(0 \%)\end{array}$ & 27
\end{tabular}

表 7 術後の患者の受診状況

両側手術例はそれぞれの手術側耳の観察期間を示した。

\begin{tabular}{c|r|r|r|r|r|r|r|r|r|r|r|r}
\hline \hline 手 術 年 度 & $\mathrm{S} 51$ & 52 & 53 & 54 & 55 & 56 & 57 & 58 & 59 & 60 & 61 & 計 \\
\hline 観察期間 & & & & & & & & & & & & \\
$2-11$ (月) & 2 & 5 & 5 & 8 & 14 & 9 & 7 & 2 & 15 & 12 & 29 & 108 \\
$12-23$ & 1 & & 4 & 5 & 4 & 4 & 5 & 6 & 6 & 11 & & 46 \\
$24-35$ & & & 2 & 2 & 4 & 5 & 5 & 9 & 6 & & & 33 \\
$36-47$ & & 1 & & 1 & 4 & 1 & 7 & 3 & & & & 17 \\
$48-59$ & 1 & 1 & 3 & 5 & 3 & 5 & 3 & & & & & 21 \\
$60-$ & 1 & 8 & 2 & 1 & 4 & 2 & & & & & & 17 \\
\hline 計 & 5 & 15 & 16 & 22 & 32 & 26 & 27 & 20 & 27 & 23 & 29 & 242
\end{tabular}


るので，中耳の含気腔を保つための耳管の負担 が㹩減できる，3）術後の乳突润昞変の倠察が 容少である，といった長所がある。一力，外耳 逆を保存して closed method とすれば，1） 自然の外耳道の形態が保存でき, 外耳の共鳴特 性を障害しない，2）術後処置が容罗で，短期 日で耳内が䡉燥上皮化する，また術後のケアも

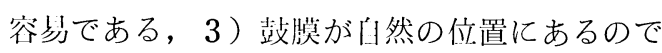
川耳腔を保て，耳小骨辿鎖再建が容貥になる， といった長所がある。しかし，お互いの術式の 長所が他の術式の短所でもある。我々はこれま での経験から closed method の短所は段階的 手術を行うことにより光服できると考え，でき る限り外耳逆を保存するようにしている.

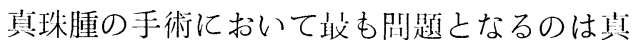
珠腫の再発と術後䏇力である. 今回の我々の成 績では，段階的手術による closed methodの 成績は鿣力の予後や真珠腫再発頻度の点で open methodよりも優れていた. しかし， open methodを用いた症例はもともと病変が 高度であった症例であり，そのまま此較するこ とはできない。また第二次段階手術垨に真洙腫 の䢖残している割合は closed method に限る と45.6\%と, むしろ open method の豩今 (23 \%)よりも高いわけで, 外耳近後壁を保存する と, 真珠腫の除去が不徹底になりやすいととが 分かる.さらに外耳逆後壁を保存して段階手術 をおてなっても，第二次段階手術時に真珠腫の 遺残再発のためにその保存が不可能々判断し, 結局, 後壁を削開した症例が 7 耳あるわけで, いろいろの長所があるとしても, 単純にすべて の症例に closed method を抗てなうべきとは 考えていない. 結局, 乙の拈扒は挤変の程度や 術者の経験から決められるべきもので, 症例に 忍じて適切な術式を選扒する必要がある。

今回の closed methodの経過観察で特に問 題と思われたのは, 術後に retraction pocket を形成する頻度がかなり高いことである。乙れ

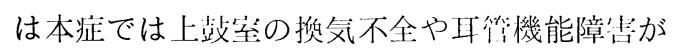

背景にあるためと考えられる。最近，我々は closed methodを行った症例に対しても乳乲 洞の病変を垶消した後, mastoid cavity obliterationを行い艮好な絬果を得ている。やは り retraction pocketを予防するためには乳 突洞腔を閉鎖するなどの対策が必要であろう.

鼓室形成術による恥力改善成績には, 病変の 程度, 耳管機能, 術者の技術, 耳小骨迎鎖再建 材料など多くの因子が関与する，今回の手術治 療成績によると，I型やП型では成划率は高 く, 次いでIII型変法やIV型変法で良く, III型や IV 型では改善例が少ない結果であった。概して III型変法に比べIV型変法の成績は艮くないが, アパセラム使用例では成功率が高く注目され $ろ^{2)}$.

手術後の䋂過倠祭は，特に真珠腫症で重要だ が, 今回の調查絬果からは必ずしも術後の受診 状沉は艮くない，乙れは遠方在住の患者の便宣 を考え，できる限り近队に綠介し，閌題があれ ば些科に再受診させるようにしていたからであ る.てのう法で，はたして本当に近经で十分な 微察がされているか疑問もあるが，今後の検㳡 訓題としたい．また，術後どのくらい微察が必 要かについても議論はあるが, 鈴木5) が述べて いるように，再発の点を考えれば 5 年程度の峴 祭が必肾であろう。

\section{まとめ}

当院開設以来 9 年 9 ケ月間に行った真珠腫症 例について, 術前および術中所罗, 手術術式, 術後㯖力, 真珠腫の再発, 術後の問題点などに ついて検楌を行った。外耳逆後壁を保存して段 階的喆室形成術を行った症例では, 真珠腫の再 発や術後聡力などの点で他の術式よりも優れ ていたが，かなりの制合で retraction pocket がみられることから，てれを防止するための対 策が必要と考えられた。

本論文の要旨は第13回日本臨床耳科学会において発 表した。 


\section{参考文献}

1) 柳原尚明：真珠腫症の手術的治療. 耳鼻臨床 74 :2179 2185, 1981.

2）佐伯忠彦, 兟 清文, 柳原尚明, 他：ハイドロキ シ・アパタイトによる耳小骨連鎖再建の手術成 績. 耳鼻臨床 $79: 1063 \sim 1071,1986$.

3 ）柳原尚明, 藤田 寛, 堤昭一郎：乳突・鼓室 - 外 耳道の一次的全閉鎖術. 耳喉 $54: 597 \sim 602$, 1982.
4) 中野雄一: 真珠腫性中耳炎. 臨床耳鼻咽喉科. 頭 頸部外科全書 $2 \mathrm{~A}$ 臨床 1 (大内 仁, 中野雄一編) 319～335頁，金原出版，東京， 1986.

5 ）鈴木淳一：伝音性難聴へのアプローチ. 261頁, 篠原出版, 東京, 1983.

$\left(\begin{array}{l}\text { 原稿採択 : 昭和 } 61 \text { 年11月19日 } \\ \text { 別刷請求先：暁 清文 } \\ \text { T791-02 愛媛県温泉郡重信町志津川 } \\ \text { 愛媛大学医学部耳鼻咽喉科学教室 }\end{array}\right)$

